\title{
MA Defence: “Corporate Social Responsibility in the Canadian Mining Sector: Rhetoric, Ethics, and the Economy" By Heidi Wudrick
}

\section{Sibo Chen}

School of Communication

Simon Fraser University

Our dear colleague, Heidi Wudrick, will defend her MA Thesis on April 10th, 2015 at Harbour Centre, Room 1530. Here is the abstract of her thesis "Corporate Social Responsibility in the Canadian Mining Sector: Rhetoric, Ethics, and the Economy":

\begin{abstract}
Corporate Social Responsibility (CSR) has been promoted by the Government of Canada and Canadian mining companies as an appropriate model of self-regulation, accountability, and communication with the public since the launch of Canada's 2009 CSR strategy for Canadian companies engaged in the international extractive sector. This thesis contextualizes CSR in the recent history of Canadian mining activity nationally and internationally, considering broad shifts in government communication and approaches to regulation. It applies a rhetorical analysis to CSR discourse, suggesting that Aristotle's categories of epideictic (celebratory) and deliberative rhetoric demonstrate how the strategic CSR communication of mining firms and government limits genuine debate and replaces it with a discourse prioritizing CSR's economic benefit over human rights, indigenous land rights, and labour and environmental concerns.
\end{abstract}

